\title{
Inventory Management and Reorder Point (ROP) Strategy Using ABC Analysis Methods in Textile Manufacture
}

\author{
Teuku Faisal Umry ${ }^{1}$, Moses Laksono Singgih ${ }^{2 *}$
}

\begin{abstract}
Tight competition encourages textile companies to increase their competitiveness to efficient in all fields, especially by reducing material stock to its optimum figures without disrupting production operations. Currently this textile manufacture has implemented SAP as an enterprise resource planning (ERP) software. SAP is currently used as material resources planning (MRP), purchasing and inventory control software. Purchases are made automatically using reorder point (ROP) and inventory control using the $A B C$ analysis method. In time being there is no relationship between the $A B C$ analysis method to inventory control and ROP. With this condition, the purchase order for material is raised when the stock level is lower than ROP even these unnecessary, causing the stock to become slow moving and dormant when it reaches six months laying on the warehouse and causing excess inventory. This study aims to design and implement how the $A B C$ method can be used to determine purchasing decisions and which ROP calculations should be used. The ABC multi criteria analysis in this study shows that $A B C$ categorization is acceptable for deciding ROP determination. This method of inventory management has the potential to reduce inventory levels up to $17 \%$ and eliminate dormant and slow moving.
\end{abstract}

Keywords-Reorder Point (ROP), ABC Analysis, AHP Multicriteria ABC, Purchasing, Inventory Control.

\section{INTRODUCTION}

The lean manufacturing concept is commonly known in manufacture industry to minimize waste or waste. One of the waste that is inventory itself because no added value when we keep inventory at warehouse. Lean manufacturing born from the Toyota production system does not even have a storage warehouse because raw material from suppliers only send when needed directly to the production line [1].

The purpose of inventory management is to meet customer demand with a minimum amount of inventory. Excessive inventory will cause very high costs and affect the company's financial performance [2]. Excessive inventory means excessive working capital. One of the ways to improve company performance is to reduce working capital. Related to this inventory management is

\footnotetext{
${ }^{1}$ Teuku Faisal Umry, Department of Management Technology, Institut Teknologi Sepuluh Nopember, Surabaya, Indonesia, faisalumry@gmail.com

${ }^{2}$ Moses Laksono Singgih, Department of Management Technology, Institut Teknologi Sepuluh Nopember, Surabaya, Indonesia, moseslsinggih@ie.its.ac.id
}

very important. Existing stock needs to be tightly controlled so as not to disrupt the company's financial performance. To control inventory there is two production system related to this i.e make to stock and make to order.

The research conducted by Jan Olhager and Daniel I. Prajogo stated that there were differences in the application from which side the improvement is carried out, whether from the external or internal side of the company. Make to stock model's improvement should be carried out on the internal side of the company while make to order model's can make improvements on the external side of the company such as integration of logistics with suppliers [3].

In inventory management is commonly used $\mathrm{ABC}$ analysis method to separate items based on pareto diagrams. ABC analysis is easy to use and understood by many people. Usually the classification is based on the number of usage or the number of requests per year [4]. While ROP is commonly used to determine at what point the stock will be purchased. In empirical research, it was found that ROP had better control systems using ROP than using Material Resource Planning (MRP) [5].

Textile companies in this study is company that produce sewing thread used in the garment and footwear industry, also produce threads for other industrial needs, for example, tires, fiber optics, airbags, car seats, etc.

Filament yarn material imported from China and Vietnam using sea freight. The material is then processed into sewing thread. Determination of goods to be produced is done subjectively. This then becomes a problem because not all goods that are sales are sustainable. The problem that occurs is order fulfillment and also material nor finished goods that become dormant stock and slow moving.

The company uses systems applications and products in data processing (SAP) as ERP software. All transactions are real time. The purchase decision uses a uniform ROP formula without discriminating whether material needs to be purchased or not. The ERP will automatically issue a purchase order when the stock reaches the ROP point.

Filament yarn material is then processed into sewing thread using the principle of make to stock and also make to order. Determination of goods will be produced with a system which is done subjectively. Then becomes a problem because not all goods whose sales are continues and can also be goods that are initially one-off-order goods 
then the order becomes continues order. The problem that occurs is the fulfillment of late orders and also material and / or finished goods that become dormant stock and slow moving. In 2018 there were dormant and slow moving and the biggest was in August there were two materials that were slow moving because of the improper purchasing strategy with a large value of USD 76,251.

TABLE 1.

DORMANT AND SLOW MOVING LIST 2018

\begin{tabular}{lccc}
\hline \multicolumn{1}{c}{2018} & Items Total & Quantity (kgs) & Value (USD) \\
\hline January & - & - & - \\
February & - & - & - \\
March & - & - & - \\
April & 3 & 2,488 & 4,873 \\
May & 1 & 125 & 237 \\
June & 1 & 2,065 & 4,089 \\
July & 1 & 2,211 & 438 \\
August & 2 & 31,243 & 76,251 \\
September & - & - & - \\
October & - & - & - \\
November & 1 & 461 & 1,360 \\
December & 1 & 559 & 1,649 \\
\hline \hline
\end{tabular}

This study aims to design and implement raw material purchasing decisions based on ROP using ABC analysis. Detail of study objective as follow:

1. Effectiveness of ABC multi criteria analysis method using the AHP method to determine other factors that affected inventory.

2. What is the difference between classic ABC analysis and ABC multi criteria analysis and how far other factors impact of purchasing strategy.

3. Can the ABC multi criteria analysis be used to determine the ROP strategy in inventory management.

4. Does all materials need to be applied to the ROP strategy for purchasing decisions.

5. How much the potential inventory reduction when using ABC multi criteria analysis and how effective it is to eliminate dormant and slow moving.

\section{LITERATURE REVIEW}

\section{A. Inventory}

There are two types of inventory definitions based on the type of company Chase, Jacobs \& Aquilano in his book Operation Management provides a definition of inventory in manufacturing companies as all items that contribute or become part of finished goods. Inventories in manufacturing companies generally consist of raw materials, finished goods, auxiliary materials, component goods, and goods that are on the production line [6].

\section{B. ABC Analysis}

Distribution of products with categories $\mathrm{A}, \mathrm{B}$ and $\mathrm{C}$ generally uses the $80-20$ principle. Product $A$ is $70 \%$, product $\mathrm{B}$ is $20 \%$ and product $\mathrm{C}$ is $10 \%$. This percentage can be taken from the amount of inventory or the number of purchases in each year [7]. In other words, product category A is the product with the largest amount of inventory in product value and amount of inventory, but the number of products in category $\mathrm{A}$ is small. Whereas products with category $\mathrm{C}$ are products with large amounts but a small amount and value of inventory.

Classic ABC analysis has been applied in many enterprise resource planning (ERP) with the aim of effective inventory management. However, classical ABC analysis is hampered by the fact that it uses a single criterion and ignores other important factors such as the lead time of purchase and production, costing, criticality and other factors that significantly influence. Classical ABC analysis must be replaced with a multi-criteria approach to manage inventory more efficiently. Multi criteria classification requires techniques that are able to provide accurate classifications to manage large quantities of inventory [8].

\section{Analytic Hierarchy Process (AHP)}

Saaty developed the Analytic Hierarchy Process (AHP) as a tool for decision making from several factors that must be achieved into a single hierarchy. AHP describes something complex and unstructured into objective elements, factor elements, elements of criteria, elements of sub criteria up to the last element of the existing alternatives. These elements are subjectively given a relative assessment based on a comparison scale so that they can be synthesized quantitatively [9].

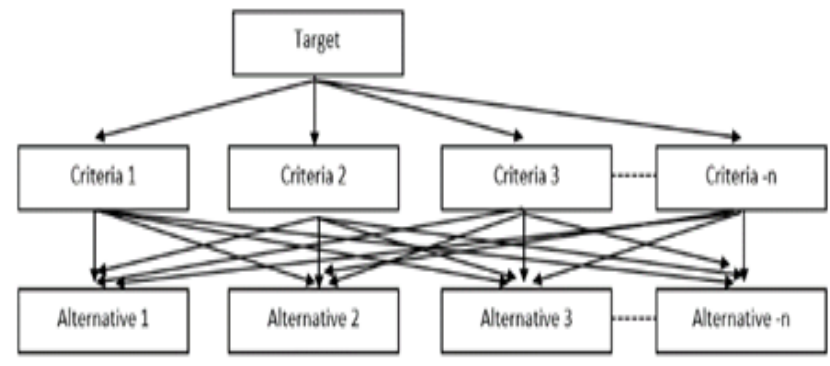

Figure 1. Analytical Hierarchy Process Structure (AHP)

Flores specifically developed AHP to be used in determining $\mathrm{ABC}$ categories in inventory. There are four most important elements in inventory control, namely the average cost, the purchase cost in a year, the critical level and lead time. The implementation of this method is then synthesized into one destination variable, UTILITY. Critical level elements can cause a large impact on inventory control and also the possibility of supply scarcity. Critical level is lowered again into three sub elements ie impact, scarcity and substitution [7]. 


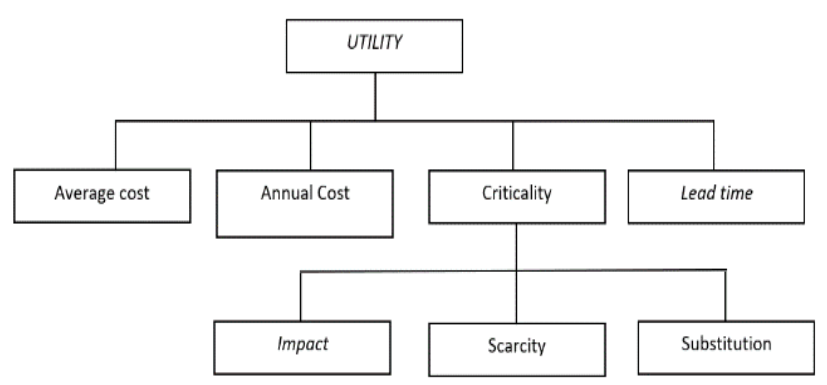

Figure 2. Inventory control Hierarchy AHP

Weighting each factors that affect inventory according to Flores.

$7.9 \%$ average cost +9.2 annual cost $+28.1 \%$ Impact $+10.1 \%$ Scarity $+3.7 \%$ Substitution $+41 \%$ Lead time ;

Total 1.0

\section{Re-order Point}

The choice of inventory strategy depends on how often the inventory level is checked. Inventory management policies in companies with random demand fluctuations are divided into two categories, namely continuous review policy and periodic review policy. Continuous review policies are more expensive in terms of costs than periodic policies, but continuous checks are very useful for achieving and maintaining the desired level of service from slow moving materials [10].

Inventory is important to cover fluctuations in sales demand and also production fluctuations. Inventories are managed at an optimum point, not too much but also not run out. Too much inventory causes working capital too high and bad for company's financial, while the run out of inventory causes a loss of sales nor stop the machine. For this reason, the inventory needs to be managed to be at its optimum point, not too high and not too low. To manage inventory, it is necessary to determine at what point the inventory must be added to maintain inventory at the optimum point. The point of adding inventory to the continuous review policy is done when the inventory level has reached the reorder point (ROP) point [11].

To manage inventory, it is necessary to determine at what point the inventory must be added to maintain inventory at the optimum point. This point is commonly known as Reorder point (ROP). The question of when the order must be made is determined by how many requests for a certain period and how long it will take to get the order (lead time).

This can be formulated as the number of requests (d) in a certain time period multiplied by lead time (L) to get an order where the unit of time between lead time and demand is the same [12].

$$
R=d L
$$

The number of requests is assumed following a normal distribution and used to measure customer demand information. As well as lead time is also considered to follow a normal distribution [13][14]. The ROP formula is only valid if the order lead time is smaller than the inventory cycle time. Inventory cycle time is how many orders are made in each year to meet needs. The number of orders in each year can be calculated based on how much the most economical order in each order is known as an economical order quantity (Q)

$$
Q=\sqrt{\frac{2 C R}{H}}
$$

Where:

$\mathrm{Q} \quad=$ Economical order quantity (EOQ)

$\mathrm{R} \quad=$ Annual demand

$\mathrm{C} \quad=$ Ordering cost per order

$\mathrm{H} \quad$ = inventory holding charges per unit per period.

Inventory cycle time determined as

$$
t=\frac{T}{N}
$$

Where:

$\mathrm{t}=$ cycle time

$\mathrm{T} \quad=$ period (year)

$\mathrm{N} \quad=$ order number per year.

As explained previously the basic formula of ROP can only be used if the order lead time is smaller than the inventory cycle time because it is not possible for orders to be made when the inventory level is greater than the order [12].

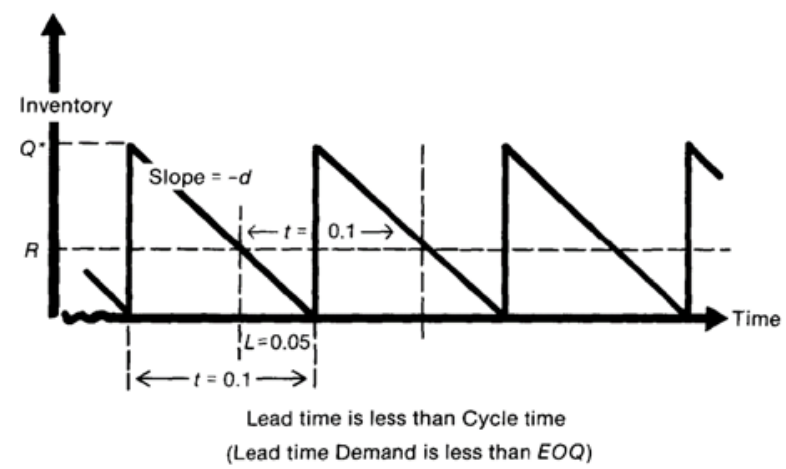

Figure 3. Reorder Point [12]

The number of demand and lead time basically affects the reorder point when the demand is known, basically the determination of the reorder point is sufficiently determined from the lead time of the order itself. When the lead time is known but demand moves fluctuating and cannot be determined, the ROP formula needs to consider the safety stock to overcome the fluctuations in the demand.

$$
R=d L+S-\left[\frac{L}{t}\right] Q^{*}
$$

Where:

$\mathrm{R} \quad=\mathrm{ROP}$

$\mathrm{d}=$ Demand in certain period

$\mathrm{L} \quad=$ Lead time 
The $1^{\text {st }}$ International Conference on Business and Management of Technology (IConBMT)

August 3rd 2019, Institut Teknologi Sepuluh Nopember, Surabaya, Indonesia

$$
\begin{array}{ll}
\mathrm{S} & =\text { Safety stock } \\
\mathrm{t} & =\text { Inventory cycle time } \\
\mathrm{Q}^{*} & =\text { Economic order quantity }
\end{array}
$$

Safety stock determine as [15].

$$
S S=z \alpha \times \sigma D \times \sqrt{\frac{L T}{T}}
$$

Where :

$\alpha \quad=$ service level

$\mathrm{z} \alpha=$ inverse distribution function of a standard

normal distribution with cumulative probability.

$\sigma \mathrm{D}=$ Demand Standard deviation.

LT $=$ total lead time

$\mathrm{T} \quad=$ demand time unit.

Safety stock is an additional inventory to anticipate natural demand and lead time fluctuations. Safety stock exists when there is uncertainty in demand, purchase lead time and lead time for producing the item, safety stock to ensure the company does not experience out of stock and cannot supply its customers.

\section{RESEARCH METHODOLOGY}

The method of this research is that case studies in textile companies are quantitative research. The outline of this research can be seen in figure 4 below.

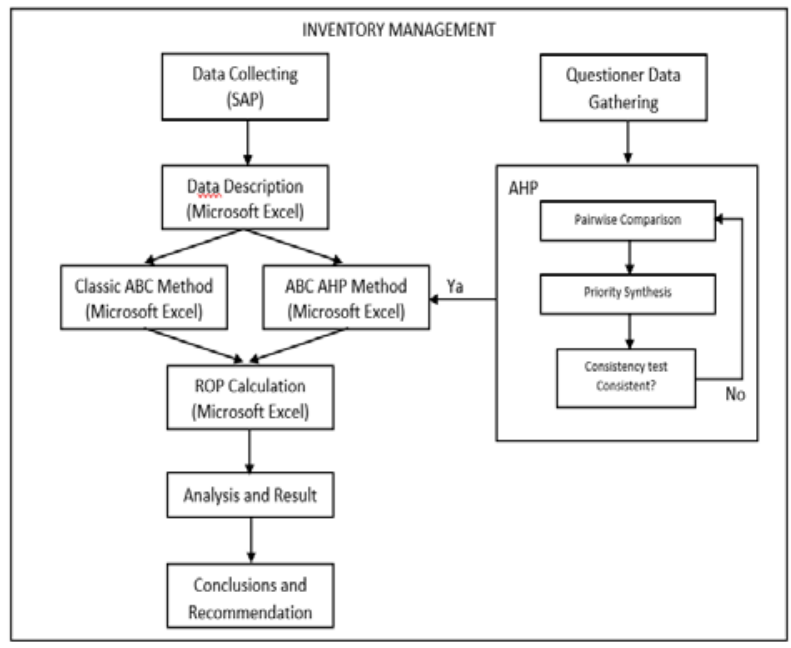

Figure 4. Research Outline

To determine the ABC category, need to consider factors other than the total value of purchases in a year. For this reason, the AHP method is used to determine the ABC category that is more appropriate. The criteria considered in determining the ABC category are compared with one another and which categories are more important and how important. The opinion of experts involved in the field of purchasing and inventory is needed.

The population in this study is all data on purchases and raw material requirements in one textile company within one year from 01 January 2018 to 31 December 2018. This data is obtained by taking from enterprise resource planning (ERP) software from the company.

The data obtained were then analyzed using the classic ABC method and also the ABC multi criteria method using AHP and determined by the ROP

\section{ANALYSIS AND RESULT}

\section{A. Classic ABC Analysis}

Table 1 is a grouping of materials based on Classic ABC

\begin{tabular}{|c|c|c|c|c|c|c|}
\hline No & Item & Value (USD) & Pareto & Percentage & $\begin{array}{c}\text { \% Pareto } \\
\text { Accumulative }\end{array}$ & Category \\
\hline 1 & 86000037 & $4,230,020$ & $4,230,020$ & $30.98 \%$ & $31 \%$ & $A$ \\
\hline 2 & 86101151 & $3,562,137$ & $7,792,157$ & $26.09 \%$ & $57 \%$ & A \\
\hline 3 & 86100915 & $1,138,807$ & $8,930,964$ & $8.34 \%$ & $65 \%$ & $A$ \\
\hline 4 & 86000003 & $1,002,141$ & $9,933,105$ & $7.34 \%$ & $73 \%$ & $B$ \\
\hline 5 & 86000039 & 970,519 & $10,903,624$ & $7.11 \%$ & $80 \%$ & $B$ \\
\hline 6 & 86100755 & 368,395 & $11,272,018$ & $2.70 \%$ & $83 \%$ & $B$ \\
\hline 7 & 86000016 & 323,329 & $11,595,348$ & $2.37 \%$ & $85 \%$ & $B$ \\
\hline 8 & 86100756 & 293,185 & $11,888,532$ & $2.15 \%$ & $87 \%$ & $B$ \\
\hline 9 & 86101221 & 237,539 & $12,126,072$ & $1.74 \%$ & $89 \%$ & $B$ \\
\hline 10 & \begin{tabular}{|l|}
86100957 \\
\end{tabular} & 236,303 & $12,362,374$ & $1.73 \%$ & $91 \%$ & $C$ \\
\hline 11 & 86000030 & 178,048 & $12,540,422$ & $1.30 \%$ & $92 \%$ & $C$ \\
\hline 12 & 86000043 & 168,625 & $12,709,048$ & $1.24 \%$ & $93 \%$ & $C$ \\
\hline 13 & 86100955 & 145,079 & $12,854,126$ & $1.06 \%$ & $94 \%$ & C \\
\hline 14 & 86101190 & 118,024 & $12,972,150$ & $0.86 \%$ & $95 \%$ & $C$ \\
\hline 15 & 86000015 & 92,929 & $13,065,080$ & $0.68 \%$ & $96 \%$ & C \\
\hline 16 & \begin{tabular}{|l|}
86100757 \\
\end{tabular} & 78,863 & $13,143,943$ & $0.58 \%$ & $96 \%$ & $C$ \\
\hline 17 & 86101223 & 76,103 & $13,220,046$ & $0.56 \%$ & $97 \%$ & $C$ \\
\hline 18 & 86000041 & 67,250 & $13,287,297$ & $0.49 \%$ & $97 \%$ & $C$ \\
\hline 19 & 86000040 & 63,653 & $13,350,950$ & $0.47 \%$ & $98 \%$ & $C$ \\
\hline 20 & 86101150 & 58,800 & $13,409,750$ & $0.43 \%$ & $98 \%$ & $C$ \\
\hline 21 & 86000021 & 54,369 & $13,464,119$ & $0.40 \%$ & $99 \%$ & $C$ \\
\hline 22 & \begin{tabular}{|l|}
86000038 \\
\end{tabular} & 53,047 & $13,517,166$ & $0.39 \%$ & $99 \%$ & $C$ \\
\hline 23 & 86100956 & 44,821 & $13,561,987$ & $0.33 \%$ & $99 \%$ & $C$ \\
\hline 24 & 86000020 & 36,305 & $13,598,292$ & $0.27 \%$ & $100 \%$ & $C$ \\
\hline 25 & 86000044 & 11,628 & $13,609,920$ & $0.09 \%$ & $100 \%$ & $C$ \\
\hline 26 & 86100954 & 10,616 & $13,620,536$ & $0.08 \%$ & $100 \%$ & $C$ \\
\hline 27 & 86000047 & 10,454 & $13,630,990$ & $0.08 \%$ & $100 \%$ & $C$ \\
\hline 28 & 86000045 & 9,901 & $13,640,891$ & $0.07 \%$ & $100 \%$ & $C$ \\
\hline 29 & 86000013 & 6,650 & $13,647,541$ & $0.05 \%$ & $100 \%$ & $C$ \\
\hline 30 & 86100953 & 3,075 & $13,650,617$ & $0.02 \%$ & $100 \%$ & $C$ \\
\hline 31 & 86101253 & 1,147 & $13,651,764$ & $0.01 \%$ & $100 \%$ & C \\
\hline 32 & 86101371 & 364 & $13,652,128$ & $0.00 \%$ & $100 \%$ & $C$ \\
\hline 33 & 86101372 & 302 & $13,652,430$ & $0.00 \%$ & $100 \%$ & $C$ \\
\hline 34 & 86101373 & 260 & $13,652,690$ & $0.00 \%$ & $100 \%$ & C \\
\hline & Total & $13,652,690$ & & & & \\
\hline & & Category & Quantity & \multicolumn{2}{|c|}{ Percentage } & \\
\hline & & A & & 3 & $9 \%$ & \\
\hline & & $B$ & & 6 & $18 \%$ & \\
\hline & & C & & 5 & $74 \%$ & \\
\hline
\end{tabular}
analysis

TABLE 2.

GROUPING MATERIA BASED ON CLASSIC ABC

\section{B. Multi Criteria ABC Analysis}

Data from the respondents proceed using Microsoft Excel template that developed by Goepel [16]. Weight of each factors based on AHP. 
The $1^{\text {st }}$ International Conference on Business and Management of Technology (IConBMT)

August 3rd 2019, Institut Teknologi Sepuluh Nopember, Surabaya, Indonesia

TABLE 3.

WEIGHT EACH FACTORS

\begin{tabular}{|c|c|c|c|}
\hline Criterion & Comment & Weights & $\begin{array}{c}\text { Weights } \\
\text { Consolidation }\end{array}$ \\
\hline $\begin{array}{l}\text { 1) Average Cost } \\
\text { 2) Annual Cnst } \\
\text { 3| Lead time }\end{array}$ & $\begin{array}{l}\text { Average cost per kg material } \\
\text { Total purchase per year } \\
\text { Purchase Lead time }\end{array}$ & $\begin{array}{l}14.2 \% \\
170 \% \\
10.5 \%\end{array}$ & $\begin{array}{l}14.2 \% \\
170 \% \\
10.5 \%\end{array}$ \\
\hline 4 Critically & How Critical the Material & $58.3 \%$ & \\
\hline $\begin{array}{l}1 \text { Impact } \\
2 \text { Scarcity } \\
3 \text { Substitution }\end{array}$ & $\begin{array}{l}\text { Impact if shortage } \\
\text { Material Scarcity at Market } \\
\text { Any subtttution material? }\end{array}$ & $\begin{array}{l}45.0 \% \\
39.4 \% \\
15.6 \%\end{array}$ & $\begin{array}{r}26 \% \\
23.0 \% \\
9.1 \%\end{array}$ \\
\hline & & Total & $100.0 \%$ \\
\hline
\end{tabular}

The value of the cost factor, price and lead time are objective based on available data, while other factors are subjective according to the interview results from the inventory planner. These factors are then given a value notation to be calculated into the formula.

TABLE 4.

VALUE FROM EACH CRITICALITY FACTORS. Impact Table

\begin{tabular}{|r|l|}
\hline 1 & No Impact \\
\hline 2 & Moderate Impact \\
\hline 3 & More Impact \\
\hline \multicolumn{2}{|c|}{ Scarcity Table } \\
\hline 1 & Easy to Get \\
\hline 2 & Rare \\
\hline 3 & Very Rare \\
\hline \multicolumn{2}{|c|}{} \\
\hline Subtitution Table \\
\hline 1 & Replaceable \\
\hline 2 & Can be replaced \\
\hline 3 & Non Replaceable \\
\hline
\end{tabular}

Each factor has a different measurement unit, USD for the average cost and purchase of a year, the number of days for lead time and subjective assessment for impact, scarcity and substitution need to be converted to a scale of $0-1$ so that the assessment becomes balanced.

The formula for converting to a scale of 0-1 is:

$$
\frac{F i-F \min }{\text { Fmax }-F \min }(6)
$$

Where :

$\mathrm{Fi} \quad=$ Initial value

Fmin = Smallest value of population

Fmax $=$ Highest value of population

For example the material below.

\begin{tabular}{|c|c|c|c|r|r|r|r|c|}
\hline No & Item & $\begin{array}{c}\text { Average } \\
\text { Cost }\end{array}$ & Annual Cost & Lead Time & Impact & Scarcity & Substitution & Total \\
\hline Bobot & $14.20 \%$ & $17.00 \%$ & $10.50 \%$ & $26.30 \%$ & $23.00 \%$ & $9.10 \%$ & $100 \%$ \\
\hline $1 / 86100915$ & 23.59 & $1,138,807$ & 40 & 3 & 3 & 3 & 0.8768 \\
\hline
\end{tabular}

Then the total value is as follows:

$$
\begin{array}{r}
14 \% x\left(\frac{23.59-1.52}{23.59-1.52}\right)+17 \% x\left(\frac{1138.807-260}{4230020-260}\right) \\
+10.5 \% x\left(\frac{40-20}{30-20}\right)+26.3 \% x\left(\frac{3-3}{1-3}\right) \\
+23 \% x\left(\frac{3-3}{1-3}\right)+9.1 \% x\left(\frac{3-3}{1-3}\right)=0.8768
\end{array}
$$

After getting the weight of each material it can be continued to determine the ABC category of each material

\begin{tabular}{|c|c|c|c|c|c|c|c|}
\hline No & Item & Weighing & Pareto & Percentage & $\begin{array}{c}\% \\
\begin{array}{c}\text { Accumulative } \\
\text { Pareto }\end{array} \\
\end{array}$ & $\begin{array}{c}\text { ABC Multi } \\
\text { Criteria } \\
\text { Category }\end{array}$ & $\begin{array}{c}\text { ABC Classic } \\
\text { Category }\end{array}$ \\
\hline & 86100915 & 0.8768 & 0.88 & $10 \%$ & $10 \%$ & A & A \\
\hline & 86100955 & 0.8368 & 1.71 & $9 \%$ & $19 \%$ & A & C \\
\hline 3 & 86100956 & 0.8328 & 2.55 & $9 \%$ & $28 \%$ & A & C \\
\hline & 86100954 & 0.8314 & 3.38 & $9 \%$ & $37 \%$ & A & C \\
\hline & 86000037 & 0.5018 & 3.88 & $5 \%$ & $42 \%$ & A & A \\
\hline & 86101151 & 0.4512 & 4.33 & $5 \%$ & $47 \%$ & A & A \\
\hline & 86000038 & 0.3858 & 4.72 & $4 \%$ & $51 \%$ & A & C \\
\hline & 86000040 & 0.3544 & 5.07 & $4 \%$ & $55 \%$ & $A$ & C \\
\hline 9 & 86000041 & 0.3531 & 5.42 & $4 \%$ & $59 \%$ & A & C \\
\hline 10 & 86000016 & 0.3318 & 5.76 & $4 \%$ & $63 \%$ & A & $B$ \\
\hline 11 & 86101221 & 0.2782 & 6.03 & $3 \%$ & $66 \%$ & A & $B$ \\
\hline 12 & 86000030 & 0.2738 & 6.31 & $3 \%$ & $69 \%$ & A & C \\
\hline 13 & 86000003 & 0.2426 & 6.55 & $3 \%$ & $71 \%$ & $B$ & $B$ \\
\hline 14 & 86000039 & 0.2392 & 6.79 & $3 \%$ & $74 \%$ & B & B \\
\hline 15 & 86100755 & 0.2150 & 7.00 & $2 \%$ & $76 \%$ & $B$ & $B$ \\
\hline 16 & 86100756 & 0.2118 & 7.22 & $2 \%$ & $79 \%$ & $B$ & $B$ \\
\hline 17 & 86100757 & 0.2025 & 7.42 & $2 \%$ & $81 \%$ & $B$ & C \\
\hline 18 & 86000043 & 0.1944 & 7.61 & $2 \%$ & $83 \%$ & $B$ & C \\
\hline 19 & 86101223 & 0.1875 & 7.80 & $2 \%$ & $85 \%$ & $B$ & C \\
\hline 20 & 86000021 & 0.1862 & 7.99 & $2 \%$ & $87 \%$ & B & C \\
\hline 21 & 86000020 & 0.1856 & 8.17 & $2 \%$ & $89 \%$ & $B$ & C \\
\hline 22 & 86000013 & 0.1852 & 8.36 & $2 \%$ & $91 \%$ & C & C \\
\hline 23 & 86000015 & 0.1354 & 8.49 & $1 \%$ & $93 \%$ & C & C \\
\hline 24 & 86101371 & 0.0753 & 8.57 & $1 \%$ & $93 \%$ & C & C \\
\hline 25 & 86100957 & 0.0735 & 8.64 & $1 \%$ & $94 \%$ & C & C \\
\hline 26 & 86101372 & 0.0697 & 8.71 & $1 \%$ & $95 \%$ & C & C \\
\hline 27 & 86101373 & 0.0660 & 8.78 & $1 \%$ & $96 \%$ & C & C \\
\hline 28 & 86101253 & 0.0599 & 8.84 & $1 \%$ & $96 \%$ & C & C \\
\hline 29 & 86101150 & 0.0577 & 8.90 & $1 \%$ & $97 \%$ & C & C \\
\hline 30 & 86000047 & 0.0559 & 8.95 & $1 \%$ & $98 \%$ & C & C \\
\hline 31 & 86000044 & 0.0554 & 9.01 & $1 \%$ & $98 \%$ & C & C \\
\hline 32 & 86000045 & 0.0554 & 9.06 & $1 \%$ & $99 \%$ & C & C \\
\hline 33 & 86100953 & 0.0543 & 9.12 & $1 \%$ & $99 \%$ & C & C \\
\hline 34 & 86101190 & 0.0488 & 9.17 & $1 \%$ & $100 \%$ & C & C \\
\hline
\end{tabular}
using the pareto table.

TABLE 5.

MULti CRITERIA CATEGORY FOR EACH MATERIAL

We can see in Table 5. above there are significant differences when compared with $\mathrm{ABC}$ categories based on classical calculations. This is because we considering the critical level factors that contribute more to determination of the ABC category.

Material that was originally category B or even category C moved into category A because of the high level of criticality. There are seven materials which initially are category C become category A and two materials from category B become category A. Pareto charts are also more sloping compared to the same graph from classical ABC analysis. 


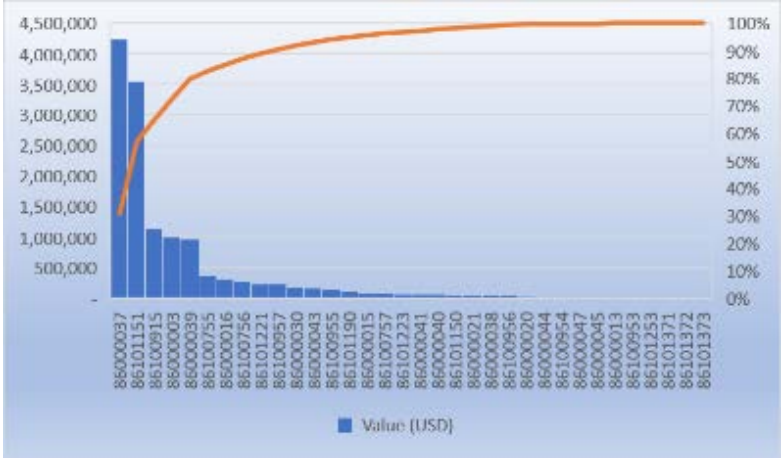

Figure 5. Pareto Chart ABC Classic.

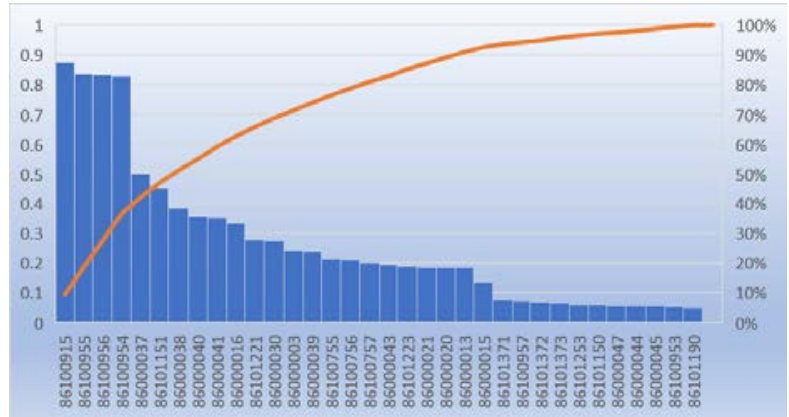

Figure 6. Pareto Chart Multicriteria ABC.

TABLE 6 .

DIFFERENCE BETWEEN ABC CLASSIC AND MULTI CRITERIA

\begin{tabular}{|c|r|r|r|r|}
\hline \multicolumn{1}{c|}{} & \multicolumn{2}{c|}{ Classic ABC } & \multicolumn{2}{c|}{ Multi Criteria ABC } \\
\hline Category & Quantity & Percent & Quantity & Percent \\
\hline A & 3 & $9 \%$ & 12 & $35 \%$ \\
\hline B & 6 & $18 \%$ & 9 & $26 \%$ \\
\hline C & 25 & $74 \%$ & 13 & $38 \%$ \\
\hline
\end{tabular}

ROP is greater than the average demand per month and EOQ is much greater than the average requirement per month. Another indicator does not need to be implemented EOQ and ROP is the number of orders per year which is less than 4 except material number 23 and 25. Based on these considerations, in addition to material number 23 and 25 do not need to be applied EOQ and ROP, material purchases will be done manually if there is any request.

TABLE 7.

THOSE MATERIAL DOESN'T REQUIRED ROP

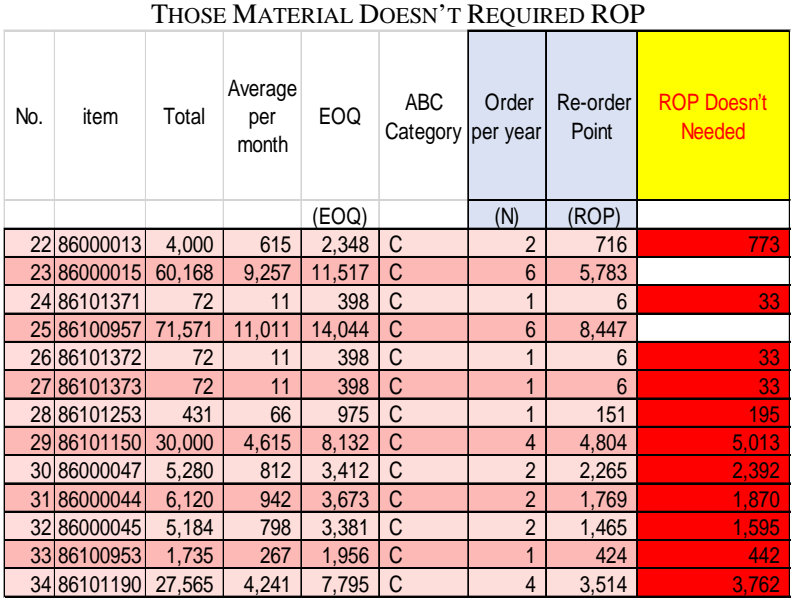

By not implementing EOQ and ROP, purchases are only made if required.

There are significant different between ROP in the company's ERP system compared to the calculations in this study.

TABLE 8.

ROP COMPARISON

\begin{tabular}{|c|c|r|r|r|r|}
\hline & & Category & $\begin{array}{c}\text { ROP in This } \\
\text { Thesis }\end{array}$ & $\begin{array}{r}\text { ERPISAP } \\
\text { System ROP }\end{array}$ & $\begin{array}{r}\text { ROP After } \\
\text { Adjustment }\end{array}$ \\
\hline No & Material & & \multicolumn{1}{c|}{ (ROP) } & \multicolumn{1}{c|}{ (SAP) } & \\
\hline 1 & 86000016 & A & $\mathbf{1 6 , 0 6 6}$ & $\mathbf{1 8 , 0 3 6}$ & $\mathbf{1 6 , 0 6 6}$ \\
\hline 2 & 86000030 & A & $\mathbf{7 , 5 4 5}$ & $\mathbf{9 , 6 8 2}$ & $\mathbf{7 , 5 4 5}$ \\
\hline 3 & 86000037 & A & $\mathbf{4 1 , 0 6 6}$ & $\mathbf{4 7 , 4 3 2}$ & $\mathbf{4 1 , 0 6 6}$ \\
\hline 4 & 86000038 & A & $\mathbf{1 , 6 2 2}$ & $\mathbf{1 , 0 2 2}$ & - \\
\hline 5 & 86000040 & A & $\mathbf{3 , 7 6 7}$ & $\mathbf{3 , 6 6 7}$ & $\mathbf{3 , 7 6 7}$ \\
\hline 6 & 86000041 & A & $\mathbf{4 , 2 1 3}$ & $\mathbf{6 , 7 8 8}$ & $\mathbf{4 , 2 1 3}$ \\
\hline 7 & 86100915 & A & $\mathbf{4 , 7 4 7}$ & $\mathbf{5 , 1 5 9}$ & $\mathbf{4 , 7 4 7}$ \\
\hline 8 & 86100954 & A & $\mathbf{1 1 2}$ & $\mathbf{1 1 0}$ & - \\
\hline 9 & 86100955 & A & $\mathbf{4 2 2}$ & $\mathbf{4 4 2}$ & $\mathbf{4 2 2}$ \\
\hline 10 & 86100956 & A & $\mathbf{6 2}$ & $\mathbf{1 8 9}$ & - \\
\hline 11 & 86101151 & A & $\mathbf{5 7 , 1 2 7}$ & $\mathbf{6 0 , 5 1 8}$ & $\mathbf{5 7 , 1 2 7}$ \\
\hline 12 & 86101221 & A & $\mathbf{1 1 , 3 1 1}$ & $\mathbf{9 , 2 0 2}$ & $\mathbf{1 1 , 3 1 1}$ \\
\hline 13 & 86000003 & B & $\mathbf{1 7 , 0 6 0}$ & $\mathbf{1 8 , 6 1 0}$ & $\mathbf{1 7 , 0 6 0}$ \\
\hline 14 & 86000020 & B & $\mathbf{3 , 7 3 8}$ & $\mathbf{4 , 3 0 3}$ & $\mathbf{3 , 7 3 8}$ \\
\hline 15 & 86000021 & B & $\mathbf{4 , 9 2 4}$ & $\mathbf{4 , 2 0 5}$ & $\mathbf{4 , 9 2 4}$ \\
\hline 16 & 86000039 & B & $\mathbf{1 0 , 4 0 4}$ & $\mathbf{1 6 , 8 3 5}$ & $\mathbf{1 0 , 4 0 4}$ \\
\hline 17 & 86000043 & B & $\mathbf{9 , 5 7 9}$ & $\mathbf{1 0 , 8 5 5}$ & $\mathbf{9 , 5 7 9}$ \\
\hline 18 & 86100755 & B & $\mathbf{5 , 0 0 2}$ & $\mathbf{6 , 1 9 7}$ & $\mathbf{5 , 0 0 2}$ \\
\hline 19 & 86100756 & B & $\mathbf{5 , 5 7 5}$ & $\mathbf{5 , 7 6 9}$ & $\mathbf{5 , 5 7 5}$ \\
\hline 20 & 86100757 & B & $\mathbf{3 , 2 3 7}$ & $\mathbf{3 , 6 9 7}$ & $\mathbf{3 , 2 3 7}$ \\
\hline 21 & 86101223 & B & $\mathbf{2 , 8 9 1}$ & $\mathbf{3 , 4 5 8}$ & $\mathbf{2 , 8 9 1}$ \\
\hline & Sub total A dan B & $\mathbf{2 1 0 , 4 6 8}$ & $\mathbf{2 3 6 , 1 7 4}$ & $\mathbf{2 1 0 , 4 6 8}$ \\
\hline 22 & 86000013 & C & 716 & 819 & - \\
\hline 23 & 86000015 & C & 5,783 & 5,963 & 5,783 \\
\hline 24 & 86101371 & C & 6 & - & - \\
\hline 25 & 86100957 & C & 8,447 & 8,436 & 8,447 \\
\hline 26 & 86101372 & C & 6 & - & - \\
\hline 27 & 86101373 & C & 6 & - & - \\
\hline 28 & 86101253 & C & 151 & 936 & - \\
\hline 29 & 86101150 & C & 4,804 & 5,412 & - \\
\hline 30 & 86000047 & C & 2,265 & 3,311 & - \\
\hline 31 & 86000044 & C & 1,769 & 4,830 & - \\
\hline 32 & 86000045 & C & 1,465 & 1,702 & - \\
\hline 33 & 86100953 & C & 424 & 930 & - \\
\hline 34 & 86101190 & C & 3,514 & 4,068 & - \\
\hline & & Sub total C & 29,355 & 36,408 & 14,230 \\
\hline & & Total & $\mathbf{2 3 9 , 8 2 2}$ & $\mathbf{2 7 2 , 5 8 2}$ & $\mathbf{2 2 4 , 6 9 8}$ \\
\hline
\end{tabular}

Total quantity of ROP in the company's ERP system is $272,582 \mathrm{~kg}$, this quantity is not far from the average warehouse stock quantity of $271,837 \mathrm{kgs}$. The ROP of the results of this study is $239,822 \mathrm{kgs}$ and after considering the average needs per month and the critical level of material, some materials are decided not to implement ROP especially material with category C.

After taken out material that no ROP strategy the total ROP quantity is $224,698 \mathrm{kgs}$, so there was a savings of $272,582-224,698=47,884 \mathrm{kgs}$, or $17 \%$. The potential saving in inventory is around USD 195,000 or IDR 2.7 billion. 
The $1^{\text {st }}$ International Conference on Business and Management of Technology (IConBMT)

August 3rd 2019, Institut Teknologi Sepuluh Nopember, Surabaya, Indonesia

\begin{tabular}{|c|c|c|c|c|}
\hline & $\begin{array}{l}\text { Re-order } \\
\text { Point }\end{array}$ & $\begin{array}{l}\text { System } \\
\text { ROP }\end{array}$ & ROP Calculation & \\
\hline Total & 239,822 & 272,582 & 224,698 & \\
\hline \multirow{2}{*}{\multicolumn{3}{|c|}{$\begin{array}{r}\text { Saving Kgs } \\
\text { Average Material Cost }\end{array}$}} & 47,884 & kgs \\
\hline & & & 4.09 & USD \\
\hline & & Saving USD & 195,725 & USD \\
\hline & & Saving IDR & $2,740,154,120$ & IDR \\
\hline & & & 14,000 & 1 USD to IDR \\
\hline & \multicolumn{2}{|c|}{ Saving Percentage } & $17.57 \%$ & \\
\hline
\end{tabular}

\section{CONCLUSION}

\section{A. Conclusion}

1. The ABC multi criteria analysis method using the AHP method is effective for determining the weight of other factors that affect inventory.

2. There are significant differences in the results of classical ABC analysis with ABC multi-criteria analysis. The coverage of categories $\mathrm{A}$ and $\mathrm{B}$ in inventory management becomes wider after considering other factors besides the factor of the number of purchases in a year.

3. Multi criteria ABC analysis can be used to determine the ROP strategy in inventory management.

4. Not all materials need to be applied ROP, especially material with category $\mathrm{C}$, which has uncertain demand and low criticality.

5. With control management using $\mathrm{ABC}$ multi-criteria analysis can reduce the amount of inventory.

6. The potential for inventory savings in textile companies in this study is two billion rupiah or a decrease in the amount of inventory to $17 \%$.

\section{B. Recommendation}

1. With different critical levels in each material, further research is expected to be able to use different ROP methods between categories A and B.

2. In determining the safety stock, it is expected that further research will also consider the forecast accuracy factor in addition to only considering the existing demand.

3. The results of this study can be continued with research to determine the algorithms that can be embedded in the company's system to create automatic systems in ROP strategies and purchasing decisions.
4. Need similar research in the industry with different characteristics to see the weight of each of the factors that affect inventory.

\section{REFERENCES}

[1] J. P. Womack, D. T. Jones, and D. Roos, The Machine That Changed The World. New York: Free Press, 1990.

[2] D. J. Bowersox, D. J. Closs, and M. B. Cooper, Supply Chain Logistics Management, 4th ed. New York: McGraw-Hill, 2013.

[3] J. Olhager and D. I. Prajogo, "The impact of manufacturing and supply chain improvement initiatives: A survey comparing make-to-order and make-to-stock firms,” Omega, vol. 40, no. 2, pp. 159-165, Apr. 2012.

[4] R. Ramanathan, "ABC inventory classification with multiplecriteria using weighted linear optimization," Comput. Oper. Res., vol. 33, no. 3, pp. 695-700, Mar. 2006.

[5] S. Axsäter and K. Rosling, "Multi-level production-inventory control: Material requirements planning or reorder point policies?,” Eur. J. Oper. Res., vol. 75, no. 2, pp. 405-412, Jun. 1994.

[6] R. Chase, R. Jacobs, and N. Aquilano, Operations Management - For Competitive Advantage, Eleventh E. McGrawn-Hill Irwin, 2006.

[7] B. E. Flores, D. L. Olson, and V. K. Dorai, "Management inventory of multicriteria classification,” Mathl. Comput. Model., vol. 16, no. 12, pp. 71-82, 1992.

[8] M. Yu, "Multi-criteria ABC analysis using artificial-intelligencebased classification techniques,” Expert Syst. Appl., vol. 38, no. 4, pp. 3416-3421, 2011.

[9] T. L. Saaty, "Decision making with the analytic hierarchy process,” Int. J. Serv. Sci., vol. 1, no. 1, pp. 83-98, 2008.

[10] M. Cardos, E. Babiloni, M. E. Palmer, and J. M. Albarracin, "Effects on undershoots and lost sales on the cycle service level for periodic and continuous review policies," in 2009 International Conference on Computers \& Industrial Engineering, 2009, pp. 819-824.

[11] K. C. Hung, "Continuous review inventory models under time value of money and crashable lead time consideration," Yugosl. J. Oper. Res., vol. 21, no. 2, pp. 293-306, 2011.

[12] R. C. Patel, "A note on inventory reorder point determination," J. Account. Educ., vol. 4, no. 2, pp. 131-140, 1986.

[13] W. F. Khan and O. Dey, "Distributed fuzzy random variable demand,” Int. J. Appl. Comput. Math., vol. 123, pp. 1-18, 2018.

[14] I. Moon and S. Choi, "The distribution free continuous review inventory system with a service level constraint," Comput. ind. Engng, vol. 27, no. 94, pp. 209-212, 1994.

[15] A. C. Rădăşanu, "Inventory management, service level and safety stock,” J. Public Adm. Financ. Law, no. 9, pp. 145-153, 2016.

[16] K. D. Goepel, "Implementing the analytic hierarchy process as a standard method for multi-criteria decision making in corporate enterprises - A new AHP excel template with multiple inputs," in Proceedings of the International Symposium on the Analytic Hierarchy Process, 2013. 